\title{
The State of Records Management Practices in Public Offices: A Case of Kinondoni Municipal Council in Dar es Salaam, Tanzania
}

\author{
Mwombeki Rutta \\ Records and Archives Management Department, Tanzania \\ Email: mwombekirutta@gmail.com \\ Esther Ndenje-Sichalwe \\ Information Studies Programme, University of Dar es Salaam \\ Email: esther.sichalwe@udsm.ac.tz
}

\begin{abstract}
This study assessed the current state of records management practices at the Kinondoni Municipal Council (KMC) in Dar es Salaam, Tanzania for good service delivery. Specifically, the study examined the state of the existing records management programme and identified the challenges encountered in managing records. The study employed a mixed methods research design that had recourse to both quantitative and qualitative approaches for data collection and analysis. Its sample of 64 respondents was selected from a population of 124 respondents using purposive sampling for top management officials and records and simple random sampling for other KMC employees comprising action officers and Human Resources Officers (HROs). Triangulation of data collection methods was employed using questionnaires, interviews, observations and documentary review. The key findings show that the KMC lacked an effective records management programme to ensure effective records management practices. Records management programme lacks institutional legal and regulatory framework, hence the largely ineffective records management practices at the KMC. Inevitably, the council contended with several challenges including lack of security measures, and lack of skills and lack of guidance from the Records and Archives Management Department (RAMD). Thus, the study recommends that the KMC should improve its records management programme by establishing legal frameworks, training staff and prioritising the records management unit.
\end{abstract}

Keywords: Records management, records management practices, records management programme, public records, public office

https://dx.doi.org/10.4314/udslj.v16i2.15

\section{Introduction}

Records and archives support performances of individuals, and public as well as private offices. Even though many public offices take measures for good records management, Ngoepe and Ngulube (2013) observed that top management in public and private sectors, do not treat records management as a crucial aspect of any successful organisation. According to United Nations (UN, 2006), good governance has eight attributes: Participatory, consensus-oriented, equitable and inclusive, responsive, effective and efficient, following the rule of law, transparency, and accountability. In fact, there is a direct relationship between these attributes and effective records management practices. Okello-Obura (2011) contends that effective records management is a source of exercising transparency, accountability and good governance. In this regard, studies such as Dikopoulous and Mihiotis (2012) and Shepherd and Yeo (2003) have underscored the value of records management in improving good governance and service delivery. Indeed, records management guarantees accessibility of complete and accurate records to facilitate decision-making and engender officers' accountability for their actions 
(Chaterera, 2016). As such, effective records management practices create a way for fostering good governance and service delivery.

In the global context, countries such as the United States and the United Kingdom (UK) established records management programmes in the 1940s to address challenges associated with records management such as lack of policies and legislations, decongestions, lack of skilled personnel and poor protection and preservation of public records. They believe that such development is achievable through good records management. The UK government highly prioritises records management to ensure the effectiveness of the programme (Williams, 2006). The origin of records management in the US lies in the US Federal government throughout the late 1940s as progress from the US archival profession (Muemi \& Rotich, 2015). According to Corporate Storage Service (2010), the United States had no standards for records management by that time, which led to a backlog of unwanted records and misplacement of records in public offices. After realising the poor state of its records management, the then US President Harry S. Truman established a Hoover Commission to make recommendations on administrative changes in the federal government. The National Archives and Records Administration (NARA) is responsible for archival and records management practices in that country. It has also the duty of inspecting public organisations' records and records management practices and can empower public servants with records management training in addition to providing service for the storage of inactive records (Office of the Federal Register, 2012).

In post-independence Africa, records management programmes also faced challenges, which inevitably resulted in poor records management. As a result, local governments had no good recordkeeping system to support their actions and serve as evidence for different transactions (Chaterera, 2016). This view was supported by a study of Keorapetse and Keakopa (2012) which found that in Africa many registries still had poor status in government structures and were administered by unskilled staff. In addition, initiatives for good records management practices were put in place by the Eastern and Southern Africa Regional Branch of International Council on Archives (ESARBICA) countries such as Zimbabwe, Malawi, and Zambia in the 1930s and 1940s (Keakopa, 2006). Botswana, for example, has taken some initiatives aimed to ensure good records management practices. Keakopa (2006) examined the development and situation of records management in Botswana and established that, the Botswana National Archives and Records Services (BNARS) had the responsibility of records management through the amendment of the National Archives and Records Services Act,1978 in 2007.

In the Tanzanian context, several initiatives have been undertaken to improve records management practices. A study by the International Records Management Trust (2011) established that Tanzania implemented the Public Service Reform Programme (PSRP) in the 1990s by establishing the National Archives to oversee the management of records in public offices. To ensure proper management of records, the government decided to shift the National Archives of Tanzania from the Ministry of Education and Culture to the President's Office - Public Service Management (PO-PSM) through Government Notice No. 289 of 1999. This shift led to the establishment of the Records and Archives Management Department (RAMD) in 2002 under the Records and Archives Management Act No. 3, 2002, which repealed the Records (Disposal) Ordinance, 1931 and the National Archives Act, 1965. Moreover, Tanzania launched the National Records and Archives Management Policy in 2011 to guide the management of both paper-based and electronic records. Mhina (2010) contends that in implementing the PSRP, the Tanzania government in 2002 established the Tanzania Public Service College under the Executive Agencies Act No.30, 1997 to train public servants, particularly records management personnel and secretaries. However, Ndenje-Sichalwe (2011) contends that the efforts made by the Tanzania government to implement the PSRP notwithstanding, the management of records within public offices remained largely poor.

Though records management is mandatory for public officers, various studies such as Katuu

The State of Records Management Practices in Public Offices: A Case of Kinondoni Municipal Council in Dar es Salaam, Tanzania 
and Van der Walt (2016), Okello-Obura (2011) and David (2017) have established that, many public offices in Africa faced challenges in managing records such as misfiling, poor filing system, loss of files and folios which resulted in poor service delivery. Moreover, studies by Ngulube and Tafor (2006), Barata et al. (2001), and Ndenje-Sichalwe (2011) and Kamatula (2010) have established that, this dire situation also exists in Tanzania. For example, the National Audit Office of Tanzania through Controller and Audit General (CAG) reports of 2014/2015, 2015/2016 and of 2016/2017 exposed lack of clear documentation for evidence as one of the key areas that hindered public offices such as KMC from attaining and upholding qualified audits. This anomaly results in inadequate records to support service delivery. This study, therefore, assessed the current state of records management practices at the Kinondoni Municipal Council to ensure good records management practices as a platform for good governance and service delivery in the public service.

\section{Objectives of the Study}

The main objective of this study was to assess the state of records management practices at the Kinondoni Municipal Council. Based on this broad objective, the study specifically addressed the following research questions:

RQ1. What is the state of records management programme at the Kinondoni municipal council? RQ2. What challenges does the Kinondoni municipal council encounter in managing records?

\section{Literature review}

The section reviews literature related to the study. It provides insight of the state of records management programme globally, Africa and Tanzania and their challenges.

\section{State of Records Management in Developed Countries}

Records management programmes are essential in organisations to ensure sound records management (Njeru et al., 2017). Such programmes entail managing records in their various stages from creation to disposition. Measuring the effectiveness of a records management programme focuses on aspects such as records management system, storage and control of records, disaster recovery plan and vital records programme, records management policies, regulations and guidelines, and appraisal and disposition of records. According to Ginsberg (2016), public offices in the US have established records management programmes, which document actions and transactions to engender public access. In fact, records of federal archival value get transferred to NARA for future reference and construction of social memory (Ginsberg, 2016). In the same vein, Australia has managed to implement the Design and Implementing Records Keeping System (DIRKS) by establishing effective records keeping system for both paper and electronic formats. Indeed, developed countries such as the UK, the US and Australia have admirably managed to initiate aspects of records management programme, for example, the classification system, policies and guidelines and security and preservation of records (Cunningham \& Robertson, 2002; Williams 2006; Smith, 2007; Ginsberg, 2016).

On the other hand, in Africa a study by Matangira et al (2013) on establishing a university records management programme found lack of a common filing system to classify their records. The study also found that there were no standards for common records classification at the University of Namibia. A study by Ngoepe and Van der Walt (2010) on a framework for a records management programme in the Department of Co-operative Governance and Traditional Affairs in South Africa found that, although there was an approved file plan, there was inadequate provision of training on how to execute the plan. In fact, the records management system at Co-operative Governance and Traditional Affairs (COGTA) was ineffective because it did not resemble business activities and clients need. In Tanzania, Ndemanyisho (2014) found that TRA lacked an effective records management system, and appropriate and adequate storage of records, which affected the records management 
programme. Whereas in developed countries records management systems have been fined tuned to work well in developing countries the systems in place largely face challenges to effectiveness.

\section{Records Storage and Security}

The effectiveness of records management programme in developed countries is enhanced by developed records management legislation and standards such as the Data Protection Act of 1998, BS 5454 of 2000, ISO 15489 of 2006. For instance, the BS 5454 of 2000 call for the storage and exhibition of archival documents standard aimed to guide the protection and preservation of records (Williams, 2006). Although developed countries had security measures on records, researchers found that in Africa the situation was different. Matangira et al (2013), for example, show that although the university had a good vital records plan against disaster, there were no standards let alone a system for managing records in all the departmental archives for future reference. Nengomasha (2013) pointed out that records management programmes in ESARBICA countries remained largely ineffective. In Tanzania, results from studies by Marwa (2015), Ndemanyisho (2014), and Kamatula (2010) show that files were lost and action officers keeping them for too long in their offices; meanwhile, the transfer of these files from one office to another occurred without prior consultation of the registry staff. These delays and loss of files affected service delivery and, eventually, accountability. Marwa (2015) found that records management programme in LGAs was ineffective because there were no security measures and preservation methods to ensure the security of records in their systems.

\section{Records Management Legal Frameworks}

The development of legislations such as the Freedom of Information Act of 2002 in the UK ensures transparency and accountability in public services, which results in good governance and service delivery through documentation of their actions and giving the public ready access to information (Smith, 2007). Ginsberg (2016) found that NARA had established retention and disposition schedules in public offices for timely appraisal and disposition of records. Cunningham and Robertson (2002) contended that there were policies and guidelines such as the Records Management Instructions Guidelines of 2002 produced by National Archives to guide records management in public offices. Cunningham and Robertson (2002), Williams (2006) and Ginsberg (2016) show that developed countries such as the UK, Australia and the US have taken initiatives of training records practitioners for effective records management. According to Cunningham and Robertson (2002), Archives of Australia has developed and conducted regular courses, workshops and seminars on how to implement the DIRKS for effective records-keeping systems. As a result, records are managed effectively in an appropriate system, which enhances transparency and accountability.

In contrast in Africa, the situation was different. Generally, the management of records in most organizations lacked records management policies, retention and disposition schedules. Ngoepe and Van der Walt (2010) found that, though the NARS Act stipulates mandate of National Archivist to authorize the appraisal and disposition of records, this was not done at COGTA. As records were not managed in accordance with policy requirements, services delivery suffered. Due to lack of retention and disposition schedules, records at the COGTA were destroyed regularly by registry staff whereas others were kept in registries without being appraised and destroyed or transferred to archival repositories as required under NARS. Another factor facilitating effective records management programme has to do with timely and authorised appraisal and disposition of records. In Tanzania, Ndenje-Sichalwe (2011) revealed that many organisations downgraded records management as a field that required unskilled personnel and one that did not need any investment in training personnel. This tendency resulted in the employment of unskilled personnel in records management, especially in African countries. Generally, in Africa, records management programmes are affected by low priority

The State of Records Management Practices in Public Offices: A Case of Kinondoni Municipal Council in Dar es Salaam, Tanzania 
given to records management; there are also no legal frameworks in many African countries to guide practices in records management, lack of skilled records practitioners and inadequate financial resources.

\section{Methodology}

The study was conducted at the Kinondoni municipal council (KMC) in Dar es Salaam, Tanzania. The KMC is one of the five municipalities in Dar es Salaam region. The Government Notice No. 4 of 2000 issued by the President's office, Regional Administration and Local Government established the $\mathrm{KMC}$ as an autonomous body. The municipal council is charged with the responsibility of delivering services to the public. Most of the council's revenue comes from levies and taxes. The KMC is one of public offices that features in CAG reports of 2014/2015, 2015/2016 and of 2016/2017.

The study used a mixed methods research design to investigate the records management practices at the KMC. However, the study was primarily quantitative due to the nature of the study, with the qualitative dimension playing a complementary role that enriched the research. In all, 64 respondents were drawn from the target population of 124 staff. Purposive sampling was used to select top management and records staff whereas simple random sampling was applied to pick action officers and HROs. Purposive sampling was applied to the two former groups largely because of their strategic roles in $\mathrm{KMC}$ related to records management whereas simple random sampling for the latter two groups ensured representativeness and non-biasness. In the final analysis, all these respondents were crucial for the study because they engaged in implementing various policies and guidelines - either directly or indirectly at the KMC.

As a mixed methods study, both the qualitative and quantitative approaches were employed in collecting and analysing data. Questionnaires used to collect quantitative data were distributed to 58 respondents comprising 11 Human Resource Officers, 19 action officers from different departments and 28 registry staff/records personnel. These questionnaires explored information on the state of records management including security measures and challenges the KMC faced in managing records. There were two sets of questionnaires: One for records personnel and the other for action officers and HROs. For qualitative data, both structured and unstructured interviews were used to collect qualitative data from 6 respondents from top management comprising the Mayor, Municipal Director and Heads of Department. There was one set of interview guide used to collect data from top management.

Moreover, the study employed non-participatory observation method to complement data collected from the questionnaire survey and interviews. Furthermore, the study used document review for some organisational documents such as strategic plans, organisational journals, staff regulations, annual financial reports, and organisational charts to collect additive data that made the study comprehensive. This technique facilitated the comparison of findings relative to the real situation on the ground. Quantitative data were analysed by using the Statistical Product and Service Solution (SPSS) for descriptions in percentages and frequencies. Qualitative data were subjected to thematic coding analysis whereby themes were arranged in accordance with the research objectives.

Data quality control was maintained by ensuring data reliability and validity before and during data collection. Pre-testing data collection instruments at KMC to determine whether it would yield the answers helped to ensure data validity. Specifically, questionnaires and interview guide were tested with records personnel and heads of department at the KMC. In addition, some questions were reviewed to ensure they met all the requirements and measured what they were supposed to measure. The study also attained reliability of data through triangulation of data collection tools. Furthermore, the study observed research protocols including obtaining necessary clearances ahead of data 
collection, getting informed consent and ensuring voluntary participation of respondents. Consequently, data were collected, analysed and discussed with a high degree of confidentiality. There was no personal interest considered during data collection and report writing.

\section{Results}

\section{State of Records Management Programme at KMC}

The state of records management programme was assessed in terms of records management policies, regulations and guidelines; records creation and classification system; tracking and use of records; separation of active and inactive records; security and preservation mechanisms at the KMC as a mandatory requirement for effective records management.

\section{Existence of Records Management Policy at KMC}

Generally, an effective records management programme requires a records management policy to guide records management practices in any public offices. Data from HROs, action officers and records personnel show that $38(65.6 \%)$ of the respondents indicated the absence of records management policy at the KMC whereas $12(20.7 \%)$ indicated the existence of a policy, and eight (13.7\%) had no idea of the existence of such a policy. In fact, it was further confirmed through interview and observation that the KMC had no such a policy. Through interview one respondent said:

... ever since I was employed I have never come across a policy covering records management $[a t K M C] \ldots$

From the study findings, it was apparent that the KMC lacked a council-wide policy to guide records management practices in the institution.

\section{Records Management Regulations, Procedures and Guidelines at KMC}

Effective records management programme requires regulations, procedures and guidelines to guide the creation, maintenance, use and disposition of records. As such, records personnel were asked to indicate whether records management regulations and procedures existed at the KMC. The results show that only $2(7.1 \%)$ respondents indicated the existence of such regulations and procedures, while an overwhelming majority $(25,89.3 \%)$ indicated the non-existence. Only 1(3.6\%) respondent was unaware of the existence of such regulations and procedures at the KMC. When respondents were further asked to mention the records management regulations and procedures available, only $3(10.7 \%)$ managed to mention the Records and Archives Management Regulations of 2007. In other words, records practitioners generally lacked awareness of regulations and procedures the government provided to initiate and ensure effective records management practices in public institutions.

The records personnel were further asked to indicate the availability of records management guidelines managing records at the KMC. The results show that $19(68 \%)$ indicated the availability of such records management guidelines whereas $5(18 \%)$ cited their absence. Another 4(14\%) respondents had no idea about such existence at the KMC. Further required this set of respondents to mention the guidelines. Fifteen (78.9\%) mentioned the National Registry Procedures Manual of 2007, and 3 (15.8\%) cited the National Desk Instructions for Registry Staff and Records Users of 2009. The remaining 1 (5.3\%) had no idea of the existence of any such guideline. During interviews with top management, one respondent

The State of Records Management Practices in Public Offices: A Case of Kinondoni Municipal Council in Dar es Salaam, Tanzania 
said:

...KMC has no written guideline of records management; we are guided by other guidelines provided by the government...

Records personnel were further asked to indicate whether the retention and disposition schedule existed at the KMC. All the $28(100 \%)$ respondents confirmed a lack of records retention and disposition schedule. Implicitly, the KMC lacked crucial information management tools and preparedness.

\section{Records Creation and Classification System used at KMC}

According to ISO 15489 (2001), records management programme requires a systematic, comprehensive, simple and usable records management system. This system captures, maintains each record created and received in public office. Thus, records personnel, action officers and HROs were asked about the system that they used to manage records. The responses indicate that $41(70.7 \%)$ of the respondents reported that the KMC used the alphanumerical system to manage records whereas $11(20 \%)$ mentioned the numerical system, and six (10.3\%) cited the alphabetical system. Overall, the respondents provided varied responses on what system the KMC deployed. This variation in responses raised further questions about the actual system in place. During an interview, one of the top management said:

...We normally use the alphanumerical system which is simple for our staff ...

This official confirmation illuminated on the system in place but also hinted at some of the staff's lack of understanding of the system they applied in their institution. In fact, the study also independently verified through observation that the KMC used the alphanumerical classification system to manage its records. Implicitly, it was neither the numerical as cited by 20 percent nor alphabetical as indicated by 10.3 percent of the respondents.

\section{File Movement Control System used at KMC}

Records are captured in a records management programme for retrieval and use in day-to-day organisational transactions. Such records need to be well-retrieved and captured by the system after being used. Magaya (2010) underscores the value of an effective file movement control system to ensure retention of records in the system in the post-use period. Doing so prevents misplacement and loss of vital records. In this regard, records personnel were asked to indicate whether the KMC had an organisational index for recording organisational files. The findings show that $18(64 \%)$ of the respondents agreed that the KMC had a file index whereas five (18\%) indicated otherwise and another five $(18 \%)$ were ignorant about the existence of such a file index at the KMC. Records personnel also mention other file movement tools deployed in tracking of file movement. Table 1summarises the list of file movement control tools the respondents indicated to exist at KMC:

Table 1: File Movement Control Tools at KMC(n=28)

\begin{tabular}{lcc}
\hline File movement tool & Frequency & Percentage \\
\hline Transit sheet & 8 & 28.5 \\
Transit ladder & 7 & 25 \\
File diary & 5 & 18 \\
Morning list book & 8 & 28.5 \\
TOTAL & 28 & 100 \\
\hline
\end{tabular}


Table 1 illustrates that, eight $(28.5 \%)$ respondents mentioned transit sheet as one of file movement control tools whereas seven (25\%) mentioned the transit ladder and five (18\%) mentioned file diary and morning list book as the tools for control files at the KMC. Moreover, the study established the maximum time used to wait for the file they sought from registry after making a requisition among HROs and action officers. Further, $12(40 \%)$ respondents indicated receiving files from registry within $1-2$ hours, $14(46 \%)$ within $10-15$ minutes, and two (7\%) indicated it took them the whole day to receive the file. Implicitly, file movement control system was not that effective at the KMC regardless of the existing file index, transit ladder, transit sheet, file diary and morning list book as file movement control tools. In other words, there was a problem in the retrieval system at the KMC because some files were obtained after two hours, and sometimes records personnel spent the whole day tracing the files.

\section{Security and Preservation Mechanism at KMC}

Effective records management programme requires a well-designed security and preservation of records against disaster and breach of public information. Records security and preservation starts with good storage in terms of space, physical condition and facilities. As such, the study assessed the state of records security and preservation among records personnel at the KMC. Records personnel were asked to identify records preservation mechanisms used to protect records against disaster at KMC. The findings are as summarised in Table 2:

\begin{tabular}{lcc} 
Table 2: Records Preservation Mechanism against Disaster $(\mathbf{n = 2 8})$ \\
\hline Records preservation mechanism & Frequency & Percentage \\
\hline Installation of fire extinguisher system & 16 & 57 \\
construction of grilled doors and windows & 12 & 43 \\
Construction of grills in at doors and windows & 12 & 43 \\
Inspection of the sprinkler system & - & - \\
Installation of CCTV Cameras & - & - \\
TOTAL & 28 & 100 \\
\hline
\end{tabular}

Table 2 indicates that $16(57 \%)$ respondents mentioned the use of fire-extinguisher for records preservation whereas $12(43 \%)$ respondents mentioned the installation of fire alarms into record office and construction of grilled doors and windows. None of respondents mentioned on installation of CCTV camera and inspection of the sprinkler system. During an interview one respondent said:

... We normally use fire-extinguisher as precautions in case of fire eruption...

Although some respondents mentioned the installation of fire alarms into the records office, there was no installed alarm observed by the study. Respondents were further asked on the existence of a vital records recovery plan. The findings show that 22(79\%) respondents disagreed on the existence of a vital record plan, two $(7 \%)$ respondents agreed with the existence of such a vital records plan, whereas four $(14 \%)$ respondents were not aware of whether KMC had a vital record plan or not. Due to these variations in the responses on the existence of a vital record plan, the study confirmed through interview when one respondent said:

The State of Records Management Practices in Public Offices: A Case of Kinondoni Municipal Council in Dar es Salaam, Tanzania 
...There is no written plan though we take care on such vital records...

Records personnel were further asked to state whether the KMC had a written disaster preparedness plan to rescue records in case of disasters occurred at the KMC. The findings indicate that 24(86\%) respondents disagreed on the presence of written disaster preparedness plan whereas one $(3 \%)$ respondent agreed that there was a written disaster preparedness plan. This finding reveals the extent to which records are at risk since there was no written plan was observed. The HROs and action officers were asked to state whether they have access to their files in the registry. The study findings also show that 20(66.7\%) respondents accessed their own files whereas $10(33.3 \%)$ did not access their own files. Furthermore, the findings show that most of the HROs and action officers managed to access their personal files, something which was unacceptable because of legal restrictions. Thus, records security and confidentiality were not adhered to in managing records at the KMC.

\section{Challenges to Ensuring Effective Records Management at KMC}

The study also assesses the challenges affecting records management at the KMC, which constrained its having an effective records management programme. The results were complemented by findings from top management collected through interviews. Table 3 illustrates the results:

Table 3: Challenges affecting Records Management at KMC $(\mathbf{n}=58)$

\begin{tabular}{lcc} 
Challenges & Frequency & Percentage \\
\hline Lack of RAMD support on records management & 32 & 55.2 \\
Lack of resources for managing resources & 28 & 48.3 \\
Lack of policies, regulations, guidelines and procedures & 22 & 40 \\
Lack of skills and knowledge among records practitioners & 13 & 22.4 \\
Low priority given to records management & 12 & 20.7 \\
\hline
\end{tabular}

Table 3 shows that the main challenge cited by 32(55.2\%) were KMC's lack of guidance and support from the Records and Archives Management Department (RAMD). As Magaya and Lowry (2011) pointed out, the PSRP initiated the establishment of RAMD to oversee records management in public offices as a mandatory requirement under the RAM Act No. 3 of 2002. However, the KMC claimed that RAMD has never visited them to provide technical advice on records management. During an interview, one respondent said:

... We have not been visited by RAMD to guide us on a suitable way of managing records ...

This neglect affected their performance as they lacked directives and technical guidance from RAMD. RAMD as the only and independent department to regulate records management activities in Tanzania has never visited KMC to provide advise them on records management. This was revealed by one interviewee who said:

... I am not aware about RAMD and their functions because they have never visited us...

Another respondent said:

... We face a lot of challenges in managing records and all of this we have not been visited with RAMD for auditing and advice ... sometime this field is downgraded because RAMD 
does not put emphasize to improve the records management situation...

The second challenge that affects records management at the KMC was lack of skills and knowledge among records practitioners, especially action officers. During interviews, one records personnel said:

... We face challenges from users of records because they lack knowledge on how to handle records, for instance, how to minute files, file handling, follow file movement, control tools when transferring the files from one office to another...

Thirdly, respondents identified lack of resources for managing records effectively as an impediment to the system in place. The overriding problem emerged to be KMC's lacking adequate budget to buy appropriate and adequate storage facilities, install security system, and train records practitioners. In this regard, one respondent said:

...We don't have enough resources to install CCTV camera in the registry and train records users...

Some records personnel were aware of the need for effective records management at the KMC; however, there were inadequate resources to support records management activities. In fact, observation established a mixing of both active and semi-active records due to lack of space

Fourth, lack of policies, regulations, guidelines and procedures emerged to be another sticking point. Although it is a mandatory requirement to develop an organisational policy, regulations, guidelines and procedures in Tanzania's public institutions, KMC had failed to develop legal frameworks to foster efficient and effective organisational records management.

During interviews, it emerged that top management were not aware of the essence of records management for fostering accountability and quality service delivery. In fact, the top management did not proactively support the records management unit in terms of sufficient budget, developing and implementing policies, regulations, guideline and procedures, training records practitioners and motivation among records personnel. In this regard, one respondent claimed:

...We lack support from our supervisors, we fail to attend short courses and we do not have any developed policy or guideline because top management does not see its essence...

Although ISO 15489 (2016) requires the top management in each office to support the enforcement of the records management policy among records practitioners in any organisation, the KMC has failed to support the records management unit in meaningful and substantive ways. In consequence, records personnel were largely unmotivated, hence lacked morale of working towards achieving good records management at the KMC. One respondent blamed the management thusly:

... We are not considered as other employees in terms of [benefiting or accessing] short courses, no one respects the contribution of records personnel [since they were not treated as a priority unit], and this affects morale to ensure records are well managed...

This situation inevitably affected records management because of the low priority accorded to organisational records management. Eventually, accountability and good service delivery at the KMC suffered since they need a functional, effective and efficient information management system for them to take root in an organisation and thrive sustainably.

The State of Records Management Practices in Public Offices: A Case of Kinondoni Municipal Council in Dar es Salaam, Tanzania 


\section{Discussion}

\section{Existence of Records Management Policy at KMC}

Results show that KMC had no Records Management Policy. This result has negative impact on the institution's records management practices. As Nengomasha (2013) contends, the management of records without a policy results tends to translate into an unsuccessful records management programme. According to ISO 15489 (2006), each public office ought to develop and communicate records management policy to all its units. Yet, at the KMC this was not the case. Without a records management policy in place, it was difficult to inculcate a culture of commitment to records management among staff since this policy document outlines the responsibilities and duties of each staff in records management system. In fact, Kamatula (2010) asserts that the records management policy benchmarks records management performance. It was also one of the most significant factors hindering the effectiveness of the records management programmes at KMC, which in turn affected organisational performance of the KMC. Similarly, Bakare et al. (2016) found that Nigerian LGAs have ineffective records management programme due to lack of such a records management policy. Furthermore, Njeru et al. (2017) found that the Parliamentary Service Commission of Kenya (PSC) had no records management programme in place due to lack of a policy governing such records.

\section{Records Management Regulations, Procedures and Guidelines at KMC}

These results indicate that, the $\mathrm{KMC}$ had no organisational records management regulations, procedures and guidelines. In consequence, the records personnel were guided by national guidelines which were even unknown to some of the records personnel. Indeed, the Records and Archives Management Act No. 3 of 2002 requires each public office to develop and enforce a retention and disposition schedule for timely appraisal and disposition of records. Although there is emphasis on developing organisational regulations, guidelines and procedures, the KMC had failed to develop and deploy such legal tools. The absence of these legal tools affected records management practices since records practitioners managed records with recourse only to their acquired experience, which provided no guarantees for novices to the organisation. Ginsberg (2016) proffered that the availability and implementation of retention and disposition schedules in public offices for timely appraisal and disposition of records creates effective records management. Yet, KMC lacked retention and disposal schedule to implement appraisal and disposition of public records. Such lack of retention and disposition schedules impacted on the illegal disposition of records as contended by Ndemanyisho (2014) contend that the TRA lacks retention and disposition schedules, which resulted in ineffective appraisal and disposition. Moreover, Ngoepe and Van der Walt (2010) observed that due to lack of retention and disposition schedules, records were destroyed regularly by registry staff and others were kept in registries without being appraised and destroyed or transferred to archival repository, which hindered effective records management.

\section{Records Creation and Classification System Used at KMC}

Though the Tanzania government embraces and underscores the Keyword system, the KMC has failed to introduce this system. Paradoxically, the KMC used the alphanumerical system, which faces many challenges such as misfiling and does not allow for expansion. Therefore, the KMC system was not effective and appropriate enough to meet the legal requirements. These findings comply with what other researchers observed in different countries. Matangira et al. (2013) observed that the University of Namibia lacked a common filing system to classify their records; in fact, there were no standards for 
common records classification because the records management systems in the university were not functioning effectively. Barata et al. (2001) contended that in Namibia records management systems were not appropriate to records created; as a result, the records in Namibia were in a poor condition. Ngoepe and Van der Walt (2010) also found that records management system at COGTA did not resemble business activities and clients' needs because the consultants employed to develop the system had failed to understand the nature of activities and records created, hence the failure to meet their needs. Some records practitioners were not even aware of the system in use for classifying records at the KMC. This non-awareness affected the records management performance because professionals' failure to differentiate between numerical and alphanumerical systems implies that they were unable to classify and index records as required to support the retrieval and utilisation of records. In consequence, there was misfiling, backlogs of records, inadequate space, bulkiness of files, loss of files, misplacement of records, and use of much time on information retrieval efforts. The same observation was made by Kamatula (2010) at the UDSM who established difficulties in filing letters and retrieving documents at the institution because of variations in the systems in use in the absence of an effective records management system.

\section{File Movement Control System Used at KMC}

The findings show that the KMC had managed to develop file movement control tools, which to a certain extent enable the tracking of post-use files in different offices. However, during data collection, some respondents were not even aware of whether the KMC had a file index. Though different file movement control tools were mentioned, action officers reported that it took up to two hours or the whole day to retrieve the file from the registry. Lack of awareness on the availability of file index among records practitioners and taking too long to retrieve the file indicate poor application of the file movement control tools available. These findings reveal that file movement system was ineffective at the KMC, which affects the retrieval and utilisation of files. The implication of ineffective control of file is that there was poor service delivery because information was not timely retrieved to support service delivery. This situation also affected good governance because information was not retrieved on time to support consistent decision-making among the governors. Furthermore, public records can be exported for individual interests without prior consent of registry staff. This situation resembles what Ngoepe and Van der Walt (2010) found to exist at COGTA, where file movement control system was not effective because only control cards and registers were used to track movement of files. Ngoepe and Van der Walt (2010) also contended that the results show that files were lost and action officers kept the file for too long in their offices and transferred files from one office to another office without prior consultation with registry staff, who inevitably remained in the dark about the movement of these files outside the established routine.

\section{Security and Preservation Mechanisms at KMC}

In Tanzania, it is a mandatory requirement to ensure the security of records by having in place a written disaster preparedness plan and vital records recovery and emergency plan. In this regard, the KMC had neither disaster preparedness plan nor vital records recovery plan. Paradoxically, some respondents were not even aware of any mechanisms for ensuring records security and preservation. Yet, the National Records and Archives Management Policy of 2011 requires security of records against unauthorised access and disaster. The policy requires each public office to ensure adequate and appropriate storage facilities, vital records recovery plan and disaster preparedness plan. Records need to be secure and preserved to elongate their lifespan to meet future evidential requirements. Although

The State of Records Management Practices in Public Offices: A Case of Kinondoni Municipal Council in Dar es Salaam, Tanzania 
the standing order of 2009 restricts access to personal files, some action officers reported accessing their files at the KMC. This situation threatened the security and preservation of records. Marwa (2015) observed the same problem at Temeke Municipal Council (TMC). According to Marwa (2015), records at the TMC were in danger to meet records life-cycle requirements because there was neither disaster preparedness plan nor vital records recovery plan. Ndenje-Sichalwe (2010) contended that Tanzania's government ministries gave security of records low priority because they did not find any written disaster preparedness plan and vital recovery programme. Records were also in danger should a disaster that could affect daily transactions strike; as such vital records could be lost.

\section{Challenges to Ensuring Effective Records Management at KMC}

The challenges affected records management at KMC were Lack of RAMD support on records management, lack of resources for managing records and lack of policies, regulations, guidelines and procedures. Also, there were lack of skills and knowledge among records practitioners and low priority given to records management. It was found that poor records management practice at the KMC appears linked to the degeneration attributable to lack of guidance from RAMD contrary to the legal requirement. Consequently, there was poor service delivery. The study findings are consistent with observations obtained at the University of Dar es Salaam by Kamatula (2010). According to Kamatula (2010), records management at the UDSM faced challenges such as congestion of records because of lack of RAMD support. Similarly, Ngoepe and Van der Walt (2010) observed in South Africa that COGTA lacked support from NARS for timely disposition of records.

Furthermore, the study found that action officers were using records without following policies and procedures conspicuous for their absence. As a result, records ended being destroyed, confidentiality was breached and files were lost mainly due to lack of skills and knowledge among action officers. Keorapetse and Keakopa (2012) had observed that lack of skills on records management among employees who deal with records has a depressing impact on records management. Although records personnel had records management qualifications, they were not competent enough to develop a records management system, and enforce policies and procedures, hence poor records management at the KMC. Although Nengomasha (2013) contended that effective records management practices depend on adequate allocation of budgets, records management unit at KMC lacked adequate budget to buy appropriate and adequate storage facilities, installing security system, training records practitioner. In fact, files were deteriorating due to poor storage facilities. Lack of resources affected the security of records because of lacking storage facilities for preserving and protecting records against disaster and unauthorised access. Marwa (2015) found the same problem at the TMC, which was affected by several factors that contribute to the deterioration of records. These were environmental, biological, chemical, and human as well as disaster factors because of lack of budgets for effective preservation. According to Kemoni and Wamukoya (2000), institutions should establish a records management policy as an organisational commitment to records management. Chinyeaka (2013) noted that the intention of the Records Management Act, policy and procedures is to guarantee proper recording of all organisational activities and decisions, with the records created, managed and kept or disposed of appropriately in accordance with proper policies and legislation. And yet, this was not the case at the KMC. Due to lack of guidelines such as retention and disposal schedule, the KMC did not appraise records. As result, it was difficult to differentiate between active records, semi-active records and inactive records as all types of records were mixed. This problematic situation resembles what Ngoepe and Van der Walt (2010) established at the COGTA where they failed to dispose of records because of lack of disposal authority. 
The study findings indicate that poor records management programme has affected better records management practices at the KMC. Effective records management programme ensures that records are available whenever needed as evidence in fraud investigations or corruption, or to facilitate the auditing process. Hence, good records management practices serve as a panacea for engendering good performance of an organisation. As such, the management of records in all public offices should be given high priority. Moreover, at the KMC the records management programme in place was too ineffective to translate into best records management practices. Consequently, the KMC was characterised by ineffective records management system, low level of skills and knowledge among records personnel, absence of records management policies, guidelines and procedures, which resulted in poor records management at the KMC. Also lack of file movement control system led to loss of files and documents. All these aspects affected the contribution of records management practices at the $\mathrm{KMC}$. Overall, it is apparent that the KMC has failed to promote better records management largely due to its ineffective records management programme.

Based on the findings and conclusion, the study recommends the following: The KMC should develop a viable records management policy and guidelines such as retention and disposition schedules to ensure the effective implementation of records management programme. The top management should also recognise the need of effective records management by prioritising the records management unit in terms of treatment and budgeting. Indeed, priority to records management can enhance the development of policies, training of staff and acquisition of appropriate and adequate records storage facilities at the KMC, which will ensure security of records and raising of levels of education among records practitioners. The KMC and other public offices need to adhere to the government strategy of establishing the Keyword filling system. Furthermore, the KMC management should establish the link between RAMD for the assistance with the records management programme. The RAMD could enhance effective records management programme, especially in developing policies, guidelines and records management systems. Additionally, the RAMD could help to install the Keyword system at the KMC. This system could enhance electronic records management for security of records by computing information and the use of back-up. The KMC should also ensure security of records by establishing a written disaster preparedness plan and vital records programme to ensure records are kept and protected against unauthorised access and disasters to ensure effective records management programme at the KMC. Through records security, confidentiality would be maintained at the highest level at the KMC. Cumulatively, these recommended records management system measures could yield better results in terms of fostering accountability and quality service delivery.

\section{References}

Bakare, A, Abdullahi, A. Abioye, A. \& Olanrewaju I. (2016). An assessment of records management practice in selected local government councils in Ogun State. Nigeria. Retrieved from http://www.jistap.org

Barata, K, Kutzner F., J. \&Wamukoya J. (2014). Records, computers, and resources: A difficult equation for Sub-Saharan Retrieved from https://www.thefreelibrary.com/Records\%2c+Computers $\% 2 c+a n d+R e s o u r c e \% 3 a+A+D i$ fficult+Equation+for...-a079742894

Chaterera, F. (2016).Managing public records in Zimbabwe: The road to good governance, accountability, transparency and effective service delivery. Journal of the South African Society of Archivists, 49, 116-136.

Chinyeaka, J. (2013). Records management in the Nigerian public sector and freedom of information Act: The horn of dilemma. International Journal of Development and Management Review, 8

The State of Records Management Practices in Public Offices: A Case of Kinondoni Municipal Council in Dar es Salaam, Tanzania 


\section{(1), 112-123.}

Corporate Storage Services .(2010). About records management, Retrieved from http://www.corporatestorageservices.com/about-recordsmanagement.html

Cunningham, K. \& Robertson, A. (2002). Establishing a high standard for electronic records management within that Australian public sector. Records Management Journal,12(3), 79-86.

David, R. (2017). Contribution of records management to audit opinions and accountability in government. South African Journal of Information Management, 19 (1), 771

Dikopoulous, A. \& Mihiotis, A. (2012). The contribution of records management to good governance. The TQM Journal 24(2),123-141.

Ginsberg, W. (2016). Retaining and preserving Federal Records in a digital environment: Background and Issues for Congress. Congressional Research Service, Report for Congress

International Organization for Standardization (ISO) 15489-1 .(2016). International Standard: Information and documentation-records management. Part 1: General. Geneva: ISO.

International Records Management Trust. (2011). Managing records as reliable evidence for ICT/ eGovernment and Freedom of Information: An East African Regional Situation Analysis. IRMT.

Kamatula, A. G. (2010). Managing records at the University of Dar es Salaam: A case study of University of Dar es Salaam. Masters' Dissertation, University of Botswana.

Katuu, S \& Van der Walt, T. (2016). Assessing the legislative and regulatory framework supporting the management of records in South Africa's public health sector. South African Journal of Information Management, 18 (1), 121-134.

Keakopa, S. M. (2006). The management of electronic records in Botswana, Namibia and South Africa: Opportunities and challenges. Doctoral Thesis, University College London.

Keorapetse, D.L \& Keakopa, S. M. (2012). Records management as a means to fight corruption and enhancing accountability in Botswana. ESARBICA Journal: Journal of Eastern and Southern Africa Regional Branch of Internatinal Council on Archives, 31, 24-35.

Marwa, H. (2015). Records preservation practices at Temeke Municipal Council, Tanzania. Master's Thesis, Moi University, Eldoret Kenya.

Matangira, V, Tjiuoro, M \&Lukileni, N. (2013). Establishing a university records management programme: A case study of University of Namibia. Journal for Studies in Humanities and Social Sciences, 2(2), 103-117.

Muemi, C \&Rotich, G. (2015). Influence of records management on service delivery in the public sector in Kenya: A case of lands department, Ministry of Lands, Housing and Urban Development. Strategic Journal of Business \& Change Management, 2 (69), 667-688.

Mhina, A. C. (2010). Desktop handbook for records and archives management. Dar es Salaam University Press.

Nengomasha, T. (2013). The past, present and future of records and archives management in subSaharan Africa. Journal of the South African Society of Archivists, 46(2), 2-11.

Ndemanyisho, A. J. (2014). Reflecting on revenue collection in Tanzania: What went wrong with records? International Journal of Education and Research, 2(8), 118-126.

Ndenje-Sichalwe, E. (2011). Records management: The role of records management in the implementation of public service reform programme in Tanzania. XXI Bi-Annual East and Southern Africa Regional Branch of the International Council on Archives (ESARBICA) General Conference on Access to Information: Archives and Records in Support of Public Sector Reform in Context, Maputo, Mozambique, 6-10 June 2011.

Ndenje-Sichalwe, E. (2010). The significance of record management to fostering accountability in the public service reform programme of Tanzania. Doctoral Thesis, University of KwaZulu-Natal, South Africa.

Ngoepe, M. \&Ngulube, P. (2013). An exploration of the role of records management in corporate governance in South Africa. SA Journal of Information Management, 15(2), 112-132. 
http://dx.doi.org/10.4102/ sajim.v15i2.575

Ngoepe, M. \& Van der Walt, T. (2010). A framework for a records management programme: Lessons from the Department of Co-operative Governance and Traditional Affairs in South Africa. Mousaion, 28 (2), 82-106.

Njeru. F, M., N, Chege, M \&Ng'eno, E. (2017). An evaluation of records management practices at the parliamentary service commission of Kenya (PSC). Saudi Journal of Humanities and Social Sciences, 2 (7), 515-522.

Office of the Federal Register. (2012). The United States Government Manual. National Archives and Records Administration. Retrieved from https://www.govinfo.gov/

Okello-Obura, C. (2011). Records and archives legal and policy frameworks in Uganda. Library Philosophy and Practice (e-journal).Paper no. 608. Retrieved from https://digitalcommons.unl.edu/cgi/viewcontent.cgi?article=1640\&context=libphilprac

Shepherd, E \& Yeo, G. (2003). Managing records: A handbook of principle and practice. Facet Publishing.

Smith, K. (2007). Public Sector Records Management: A Practical Guide. Brighton: Ashgate Publishing Limited.

United Nations (UN) (2006). Definition of basic concepts and terminologies in governance and public administration. Retrieved from http://unpan1.un.org/intradoc/groups/public/documents/un/unpan022332.pdf

Williams, C. (2006). Managing archives: Foundations, Principles and Practice. Chandos Publishing.

The State of Records Management Practices in Public Offices: A Case of Kinondoni Municipal Council in Dar es Salaam, Tanzania 